\title{
Personal Albums and Cultural Encounters: The Photo Albums at the Dutch National Maritime Museum
}

\author{
Randi Marselis*
}

\begin{abstract}
Increasingly, historical photographs and photo albums are seen as valuable museum objects in themselves, and museums are finding new ways of informing their visitors about the photo-historical aspects of their collections. Taking off from recent research on the changing role of photography in museums as well as discussions of representational ethics in relation to anthropological and colonial photography, this article examines the exhibition The Photo Albums at the Dutch National Maritime Museum. Typically, the photo collections of maritime museums include many photographs that represent cultural encounters on foreign coasts, and such photos are included in The Photo Albums. This article examines the tensions arising between the aesthetic design that encourages an immersive visitor experience and questions of representational ethics raised by photographs resulting from cultural encounters in contact zones.
\end{abstract}

Key words: photo albums, maritime museums, exhibition design, indigenous peoples, cultural encounters

In November 2015, I walked through the rooms of the east wing of the Dutch National Maritime Museum, The Scheepvaartmuseum in Amsterdam, in search of the exhibition The Photo Albums. I passed through a whole room of ship decorations, where dramatic figureheads and fluttering light effects on the floor made me a bit dizzy. I then lingered in the poetic exhibition The Navigational Instruments, where the illusion of a starry sky, ethereal soundscape, and questions such as 'Where shall I go?' disoriented me. Although I enjoyed these beautiful displays in the museum's permanent exhibition, I was relieved to reach the cosy, golden interior and light classical music of the exhibition titled The Photo Albums (Figure 1). I sat down in an armchair, reached for an album on the low table before me, and delved into old photos of life on ships and cultural encounters on foreign coasts.

This article examines the role of photo albums in the permanent exhibition, The Photo Albums, at The Scheepvaartmuseum. This exhibition seeks to introduce the visitor to maritime photographic history as well as provide an immersive experience through delving into the richness of the museum's photographic collection. The emphasis is on depth rather than breadth, with only a few albums on display. The albums in the museum's collection yield insight into how a diverse range of seafarers-from passengers and crew to nurses and Arctic explorers-experienced life on board and encounters with peoples from other parts of the world. This analysis initially discusses the use of fictitious materiality (Bessel 2015) in the design of the exhibition. This article then draws on an understanding of ships as central tools in globalization and in the creation of contact zones. In Mary Louise Pratt's terms, the contact zone 'invokes the space and time where subjects previously separated by geography and history are co-present, the point at which their trajectories now intersect' (2007: 8). Contact zones are often characterized by 'radically asymmetrical relations of power' (8), and this raises important issues of colonial power and representational ethics. Indeed, this case study confronts a critical challenge: historical photographs of 'contact zones' were usually taken by individuals from colonial powers; when these objects are displayed in non-anthropological institutions, can one correct or mitigate the biases of an imperialist perspective? What are the advantages and 
disadvantages of using an immersive environment combining sound, photographic images, and furnishings to present this material?

\section{Photographs in museum exhibitions}

The role of photographs in museums is highly complex. They have been seen as objects in themselves, but also have served as tools of museum work, where their supporting role has often been taken for granted (Edwards and Lien 2014: 3). Apart from those perceived as artworks, photographs have traditionally been placed 'low in the hierarchy of museum values' (Edwards and Morton 2015:3). Since it is possible to produce numerous photographs from a single negative, the same photographic content may be available in several museums as well as in private collections. This is at odds with the idea of museum collections being made up of valuable, unique objects; and so 'the very nature of photography, as a reproducible form, mitigates its serious consideration in the hierarchy of museum values' (Edwards and Lien 2014: 5). Moreover, in her historical overview of the use of photographs in European and American museums, Susan A. Crane describes how photographs have served as 'documentary evidence' and increasingly have been used as 'pictures in the background. Establishing historical context for other objects or staging a visual argument' (2013: 123). In relation to ethnographic displays at the Museum of Cultural History in Norway, Hilde Nielssen provides this telling list of the 'multiple functions' of photographs: '. . . they decorate, illustrate, frame, situate and "bring to life", but they also document, supplement, testify, validate and define' (2014: 58). Both Crane and Nielssen describe how photographs have been appropriated as aesthetic design elements to create the atmosphere in an exhibition. Photographs thus often have been used in a supportive role to the overall exhibition rather than as interesting in themselves, for example, when massive contextualizing murals are used to 'draw the visitor into another world' through 'exhibitionary realism' (Nielssen 2014: 64-67). However, the intersection of research areas such as critical museum history, photography history, and material culture studies has meant that historical photographs are now acknowledged as important objects that deserve curatorial attention (Edwards and Morton 2015: 7-13).

A widely used approach within photo-historical research is reconstructing social biographies of photographs by tracing their routes through different private and public contexts (Sassoon 2004a; Wanhalla 2008; Marselis and Schütze 2013; Bessel 2015). This combines well with a material approach to historical photographs that stresses the importance of studying not only image content but also the back, size, cropping, and damage, which reveal how a photograph has been handled through time. As Joanna Sassoon has pointed out, 'The physical condition of the objects, the dirt and damage, is evidence of its other lives' (2004b: 190). This increased interest in materiality can possibly be seen as a reaction to the widespread digitization taking place in cultural institutions (Edwards and Lien 2014: 6). Online catalogues, page-turning technologies, and social media genres have provided new ways of making photographic heritage available to both researchers and the wider public. However, if the materiality of photographic collections is not carefully considered, digitization bears the risk of turning photographic collections into decontextualized image content, which could harm the historical sense of photographs and minimize their complex meanings (Edwards and Morton 2015: 18; see also Edwards and Lien 2014; Sassoon 2004b).

By extension, the influence of material culture studies has stimulated interest in photo albums as valuable objects in themselves and not just as 'mere containers of data' (Dahlgren 2010: 176, see also Bessel 2015: 219). Furthermore, the photo album has been recognized as 'a medium defined by its functional uses' (Dahlgren 2010: 177). In private settings, albums have often functioned as conversation pieces or as a 'mnemonic device for storytelling' (Langford 2006: 224). Compilers of albums carefully arranged photographs and shaped visual narratives that reflected their experiences and perspectives. Martha Langford has argued that the transfer of a private album to a public collection cut 'the performative cord' (2006: 227), but that the visual narrative created by the compiler can, so to speak, be interpreted by examining an album closely. Langford's methodological strategies for how to 'reopen an album through conversation' (227) have inspired a number of studies into the role of compilers and the photo album as a narrative genre (Langford 2001, 2006; Wright 2013; Thomson 2011; Tinkler 2011; 
Marselis 2017). However, transferring this notion of photo albums as an oral/visual genre into museum exhibitions remains a curatorial challenge. My analysis of The Photo Albums at The Scheepvaartmuseum will show how the exhibition design attempted to reopen photo albums through the construction of written and oral narratives, which were based on interpretations by the museum's curator.

In a book chapter titled 'Unwrapping the layers: translating photograph albums into an exhibition context,' Ulrike Bessel (2015) describes the complex process and many contradictory choices behind a photo-historical exhibition at the Royal Engineers Museum, Library \& Archive in the United Kingdom. Bessel describes the difficult balance and compromises necessary between creating an aesthetically pleasing exhibition design and holding on to materiality and photo history as main themes of the exhibition. The original albums were displayed in cases, but scanned reproductions were necessary to show more than one page at a time. Furthermore, touch screens provided visitors with the opportunity to explore entire albums. The curators aimed at transparency by explicitly pointing out reproductions and providing information about the photographic techniques used in making the originals. Choices made during digital scanning, such as changes in size or tonal value, also were made transparent to the visitors. Bessel describes the inherent paradox of using reproductions in an exhibition on photographic materiality: 'By preserving some signs of age and usage, such as folding marks, while erasing others, like fading, a new and effectively fictitious materiality of the photographs was created' (emphasis added, Bessel 2015: 226). Since historical photographic collections are often fragile and difficult to exhibit, such 'fictitious materiality' will be a necessary strategy in many exhibitions (see also Allen 2013). This was also the case in The Photo Albums at the Scheepvaartmuseum, where the creators confronted similar dilemmas. However, the creators of the exhibition focused on creating an immersive visitor experience and didn't assume the level of transparency and attention to original materiality suggested by Bessel (2015).

\section{Representational ethics}

The attention to the material aspects of photography described above has not rendered considerations of image content irrelevant, and questions of representational ethics have been brought up especially in relation to photographs of indigenous peoples and colonized groups. ${ }^{1}$ The role of photography as a means of colonization has been acknowledged (Edwards 2001, Sandweiss 2002), and anthropological museums have been 'at the forefront of thinking critically and reflexively about their photograph collections' (Edwards and Lien 2014: 14). Photographs may be seen as traces of cultural encounters in imperial contact zones (Pratt 2007), and Edwards stresses their multi-semiotic potential:

Photographs, especially of the kinds that have historically entered European and American museum collections, are almost always, for better or worse, a site of intersecting histories - the visual legacy and historical deposits of sets of encounters and relationships. They emerge from a multiplicity of shared experiences, from the violent and intrusive to those of friendship (Edwards 2003: 83).

Museums have often privileged Eurocentric readings and silenced other perspectives, and as a result, the asymmetrical power relations of the contact zone have historically been reproduced in museum exhibitions and archival practices. Research in anthropological photographic collections has examined the use of degrading and outdated captions and reviewed how photos of quite diverse origin, such as anthropometric photography, family photographs, and commercial portraits produced for postcards, have been deployed in order to support hierarchical race theories (e.g., Edwards 2003; Edwards and Mead 2013; Morton 2014; Sassoon 2004a; McCredie 2015). Furthermore, private photo albums from the colonial period often depict the privileged life of the colonizing classes (Pattynama 2012, 2014; Marselis 2017). Since such colonial photographs may be experienced as offensive or nostalgic depictions of lost empires, curators have often found this photographic heritage difficult to use in contemporary exhibitions. However, colonial photography may be used to represent the complexities of power relations within colonial societies, as shown by Elisabeth Edwards and Matt Mead in their analysis of the now-closed British Empire and Commonwealth Museum in Bristol, United 
Kingdom. By strategically juxtaposing images, this exhibition 'foregrounded the ways in which Empire was differently experienced by colonizer and colonized' (Edwards and Mead 2013: 27 ). The difficulties of avoiding racist or celebratory readings of colonial photographs led the authors to suggest that 'some misreadings must be consciously set up in the museum space as aberrant and invalid' (32). Such didactic strategies may be particularly urgent in relation to photographs that historically have been used to underpin racist hierarchies, for instance, those recording anthropometric data.

While representational ethics have been prioritized in many anthropological museums, the relevance of these matters for other types of museums has until recently been underestimated (Edwards and Lien 2014: 14). Historical photographs from imperial contact zones are also numerous in the collections of maritime, military, industrial, and other types of museums that are representing historical processes of globalization:

Outside anthropology museums, with their problematic colonial collections, photographs are often the links between other histories and the colonial project. They intersect, for instance, with the mining of raw materials for industry, the lives of locally-born missionaries, and the colonial experience hidden in the pages of family albums (Edwards and Mead, 2013: 21).

The questions of representational ethics described above are increasingly taken up in other types of museums, where the lack of in-house expertise on colonialism (or photography, for that matter) may result in curatorial insecurities (Bessel 2015: 227). Specifically in relation to maritime museums, Heloise Finch-Boyer has examined the photo collection of the National Maritime Museum in London and pointed out how ships often 'mirrored colonial societies' (2014: 248), and her examinations of the micro-political encounters depicted in photographs from ships have inspired my analysis below. The following sections will introduce The Dutch National Maritime Museum and the design of The Photo Albums, before I return to questions of representational ethics and examine how the exhibition represents cultural encounters.

\section{The Photo Albums Exhibition}

The Dutch National Maritime Museum, The Scheepvaartmuseum, is located in a monumental building, dated from 1656, in the harbour of Amsterdam. After an extensive renovation project, the museum reopened in 2011, with two different types of exhibitions. A number of thematic exhibitions use a sensory, experience-oriented approach to appeal to broader audiences and especially to families with children, while the object-oriented exhibitions seek to illustrate the 'variety, diversity and quality' of the museum's huge collection (Schokkenbroek 2013: 161). As described in the introduction to this article, a visit to the object-oriented exhibitions in the museum's east wing requires one to walk through atmospheric rooms, each of which presents a specific category of objects such as ship decorations, atlases, navigational instruments, paintings, or photo albums, augmented by technologies including sound and light effects. The exhibition The Photo Albums is presented as an object-oriented exhibition that shows a tiny part of the museum's photographic collection. However, my analysis will show that The Photo Albums display actually features far fewer authentic objects than the rest of the objectoriented exhibitions. In fact the, design of the exhibition may be said to be more in line with the experience-oriented exhibitions in the other wings of the museum.

In line with the increased acknowledgement of photographs and albums as valuable museum objects, the introductory wall text stresses both the richness of the image content and the function of photo albums as personal memory objects:

From 1850 onwards, photography made it possible for more and more mariners and travellers (sic) to capture their own travel stories on film. This enabled them to create highly personal albums that they could share with family members and friends. Life on board the last big sailing ships and ports that have changed beyond all recognition: today, the photos in these albums bear witness to a world 
that has now disappeared. The albums present a story in pictures, but also tell the viewer something about the people who compiled them. (Introductory wall text in The Photo Albums) ${ }^{2}$

The text introduces two broad themes that run through the entire exhibition: the history of photography and photographic representations of maritime life. As visitors, we are positioned similarly to the above-mentioned relatives and friends, as we are invited to experience 'sea travel and exotic destinations' through the perspective of the compilers (Schokkenbroek, 2013: 161).

The design of the exhibition room was inspired by photos of the interiors of Dutch passenger ships sailing to the colonies of the Dutch East Indies (now Indonesia) before the Second World War. The former curator at the museum, Remmelt Daalder, has commented that salons on board were not a likely setting for studying these private albums. In creating a space reminiscent of salons on ships, his intention was to create an old-fashioned and cosy atmosphere (Figure 1). ${ }^{3}$

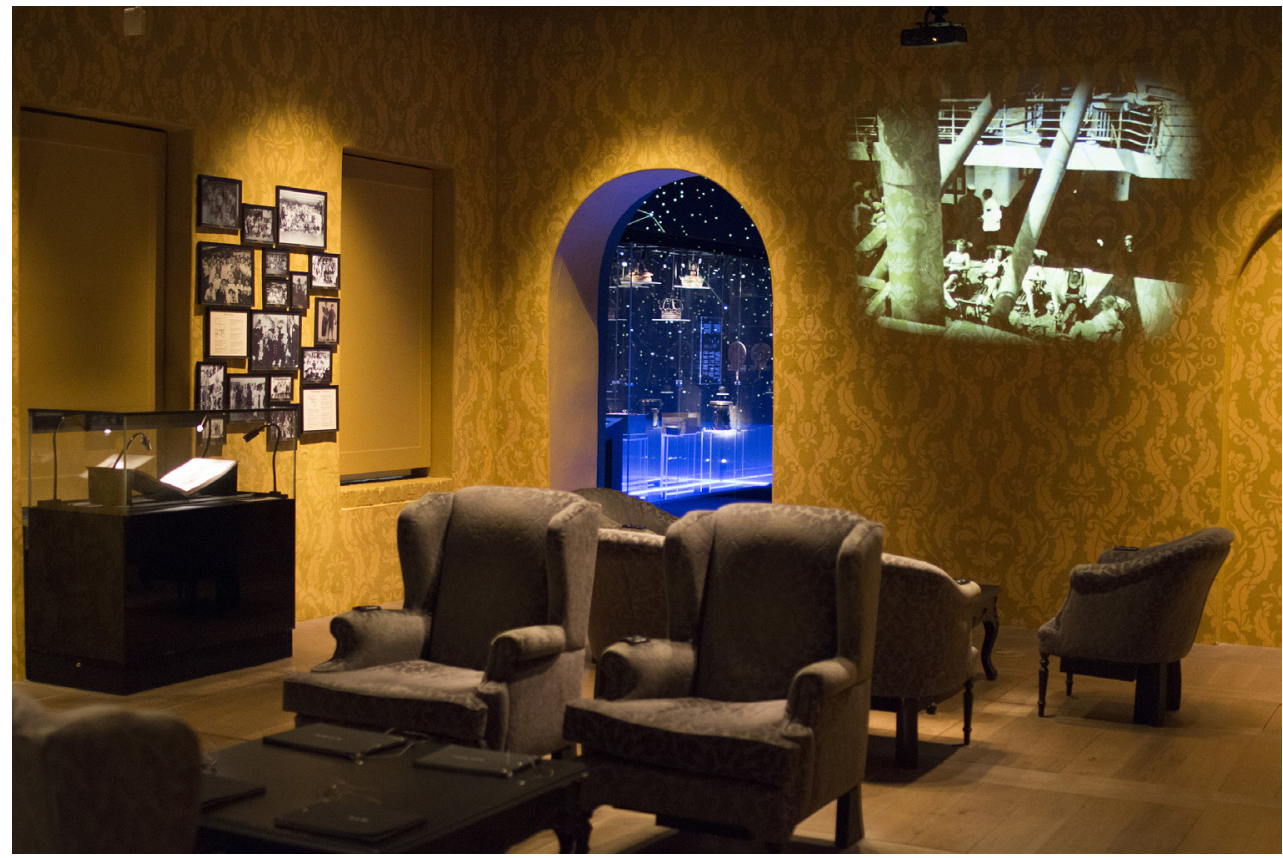

Figure 1. The Photo Albums room at Het Scheepvaartmuseum, Amsterdam, Photography by the author.

As mentioned above, strategies of fictitious materiality similar to those described by Bessel (2015) have been applied in The Photo Albums, where photographs are presented in four different ways. Slideshows based on the albums are superimposed on yellow wallpaper and add to the room's nostalgic dreamy atmosphere of bygone times and memories of maritime life. Framed reproductions hang in themed clusters on the walls. Replica albums are placed on low tables, so individual visitors can study them more closely. And finally, some of the fragile original albums are exhibited in glass cases along the walls. The former curator commented on the difficulties of exhibiting original photographs, and described how a meticulous plan for turning over pages in the albums had to be made before they were allowed to be put on display in the glass cases. Compared to the other object-oriented exhibitions with numerous, precious original objects, he described The Photo Albums as 'totally theater, all reproduction, all illusion'. ${ }^{4}$ However, as will be shown below, this use of fictitious materiality is not readily communicated to visitors. 
The exhibition is based on a tiny but varied selection from the photographic collection. The oldest album included contains rare, early photographs from Japan (1859-1869), and the latest photographs, dated 1946, show impressions from the Dutch whaling vessel and factory ship Willem Barendsz. Other examples are photographs taken during the Second World War on the Dutch hospital ship Oranje, and photographs from large passenger ships transporting migrants to South America in the 1920s. The museum staff has identified a number of recurring themes across the albums, which are used to structure the hanging of framed reproductions in groupings on the walls, where larger groups of individuals may peruse them. ${ }^{5}$ Each photograph is identified with its original caption, plus the names of the photographer and the compiler of the album (if they are known), but questions of materiality (such as the condition of the photograph) are not given attention. Additionally, the wall texts do not list the photos as reproductions, mention changes in size or include information about the original photographic techniques, such as 'reproduction of gelatine-silver print' (Bessel 2015: 225). Thus a visitor might infer that the images are originals, taken just as they are mounted on the wall, even if the technology to produce a certain size or resolution was not available at the time.

The collage-like hanging recalls private photographs in old-fashioned living rooms. The themes used in these groupings are The Ship, Work on Board, The Passengers, Party, Entertainment, Dressing Up (which seemed to be a much-loved distraction on board), Animals on Board (e.g., the ship's dog, slaughtered whales and the loading of camels and elephants), The Photographer, Geographic Identification, and finally Local Populations. Thus, while life on board the ships-and especially the privileged activities of passengers-is a predominant focus, cultural encounters with peoples on foreign coasts are also foregrounded.

A total of ten different replica albums were produced for the exhibition, and each of these is placed in front of an armchair. While the original albums vary in size, binding, and mixed materials, the replica albums are identical in design, with black covers and the name of the original compiler (not the museum staff who recreated them) printed in white on the cover. Scanned reproductions of the pages with original captions have been printed on plain, slightly glossy paper. The original narrative structure constructed by the compiler has not been kept, and some of the replicas combine material from more than one original album. In light of the increased focus on materiality and authenticity within photo history and museology, this could be seen as a controversial choice. The introductory texts in the album do mention whether the museum's collection includes numerous albums compiled by the named individual. However, neither the albums nor wall texts mention that the original structure has been disrupted or that several albums may have been combined into one replica. ${ }^{6}$

The editing and textual framing of the replica albums in other ways contribute to a rich visitor experience. My own experience of handling the replica albums was that their materiality at first disturbed the illusion of leafing through old albums, but this was quickly forgotten, as I focused on the contents and stories about the compilers. Each album provides a short biographical introduction to the compiler and information on why this particular album is of photo-historical interest. The texts tell whether the compiler purchased photographs or acted as photographer. Furthermore, some photo-historical details, such as the type of print (e.g. albumen print), are included, although this information could have been listed more systematically. The visitor can also choose to be guided through each album by an oral presentation in Dutch or English played through speakers in the armchair. This oral presentation does not resemble the compiler's own tales of travel, but is an interpretation provided by the experienced curator who knows the collection well. This soundscape created by the inclusion of oral storytelling yields an intense and intimate experience that reopens the photo albums' function as conversational pieces while masking their constructed nature (Langford 2001, 2006).

This section has described how the design of The Photo Albums invites visitors to immerse themselves in an old-fashioned atmosphere and delve into the bygone times of maritime life. The use of fictitious materiality creates an engaging exhibition and has clear advantages over photo exhibitions that mainly display original albums in glass cases. Some of the design choices made in the exhibition are at odds with the increased focus on materiality within photo research; however this could to some extent have been made up for by more transparency and additional photo-historical information. The following sections will provide a closer analysis of photographs from two of the compilers. The analysis will focus on the interplay between 
the design of the exhibition and questions of representational ethics in order to examine how seafarers' cultural encounters with foreign peoples are presented to the museum visitor.

\section{The albums of a ship musician}

The introductory text to the replica album based on Ite de Hoo's (1894-1979) private albums presents him as a 'Curious cellist amongst emigrants.' In the years 1925-1930, De Hoo sailed as a member of ship orchestras on routes to South America scheduled by the shipping company Koninklijke Hollandsche Lloyd. The replica album was based on five personal albums donated to the museum by De Hoo's daughter. Although the original structure of these albums was disrupted through editing by the museum staff, this replica exemplifies how The Photo Album presents the compiler, whose personal perspective on the world the curator attempted to 'read off' from visual narratives in the albums (Langford 2001, 2006). The curator's impression of De Hoo was that he was curious about encountering people and places: 'Life as a seaman was new for De Hoo, and things that were quite normal for experienced seamen often caught his attention. He wanted to record this for the people who stayed at home.' Visitors who are also novices to sea journeys can thus identify with De Hoo, sitting in an armchair like those on a ship, leafing through photographs from his personal collection. De Hoo's albums contain photographs from places where the ships berthed, such as street photos from Lisbon and Sao Paolo, but De Hoo was also interested in life on board and these photographs fit the themes of The Photo Albums particularly well.

On board the ship Orania, De Hoo became friends with ship photographer, Jaap Zindler (1901-1972), and De Hoo's albums are mainly based on Zindler's photographs. Interestingly, De Hoo included a number of prints of his friend photographing on deck and working in the darkroom. The themed hanging The Photographer consists of only four images, all ascribed to Ite De Hoo/Jaap Zindler. This theme has given the museum an opportunity to focus on the role of the ship photographer, a function among the crew that may not be familiar to visitors at the exhibition, but has been a vital precondition for the richness of the museum's photographic collection, and of course, ship photographers remain popular with passengers today. Finally, this themed section suggests to visitors how some of the images they see in albums might have been created.

The photographs of migrants in De Hoo's albums are also remarkable because they provide a glimpse into the diversity of the passengers; they suggest that the ships themselves were contact zones for people from diverse cultures. In the themed hanging, The Passengers, seven out of eleven photographs are ascribed to De Hoo/Zindler, and they depict life amongst Polish, Portuguese, Spanish, and Jewish migrants on their way to South America. Migrant photos are also included in the replica album, and the oral story in the armchair explains how these migrants were heading toward countries such as Colombia, Argentina, Venezuela, and Brazil. The story continues to describe the hard conditions in third class, but also tells how 'to kill time there was much singing and music. De Hoo must have made many friends along the way.' In a group photograph captioned 'Music and song III class, Emigrants and staff,' De Hoo is posing together with passengers with musical instruments, and a woman standing behind him has casually placed her hand on his shoulder. The curator's interpretation of this photograph is that De Hoo formed friendships with migrants, and that may have been the case. However, such personal relations are not reflected in his own captions, where the migrants are not individually named but collectively categorized, as, for instance, Polish or third-class passengers. The photos of migrants also reflect how Zindler and De Hoo were intrigued by their foreignness. De Hoo's fascination with diversity among the groups he encountered is evident in relation to a group portrait of three African-Brazilian children and a Polish girl, which is included in the replica album. The caption stresses visual difference and reads 'White + Brown, 3 small Brazilians 1 Polish girl.'

The way De Hoo's albums are used in the exhibition The Photo Albums maintains the crew's outsider perspective toward migrants. Neither the societal reasons behind mass migration in the 1920s nor the fates of individual migrants are included in the exhibition. In this way, the representation at The Scheepvaartmuseum as a national maritime museum is 
very different from museums that specialize in migration, such as, for instance, The Red Star Line Museum in Antwerp, Belgium, which collects migrant life stories as intangible cultural heritage (Red Star Line Museum, n.d.). ${ }^{7}$ However, migration history is neither a specialty of The Scheepvaartmuseum nor a chosen theme in The Photo Albums, and since the parts of De Hoo's albums used do not employ denigrating captions, I do not see it as problematic that the migrants are seen through the eyes of the crew represented by De Hoo and Zindler. In fact, Zindler's photos are quite sympathetic to the migrants, and may inspire visitors to think about the fates of the migrants. This could, for instance, be the case with a photograph of the Roman Catholic mass in third class (Figure 2). In a low-ceilinged room, the Catholic priest is praying in front of a travel altar. The room is densely packed with Polish migrants, and they are almost all looking toward the photographer and not at the priest. This even goes for the small children in the foreground, whose hands are folded in prayer. The many gazes toward the camera create a symbolic contact between the depicted individuals and the onlooker (Machin and Mayr 2012: 71), and their faces seem to express the seriousness and anxiety of leaving everything behind in order to build a new existence in a foreign country.

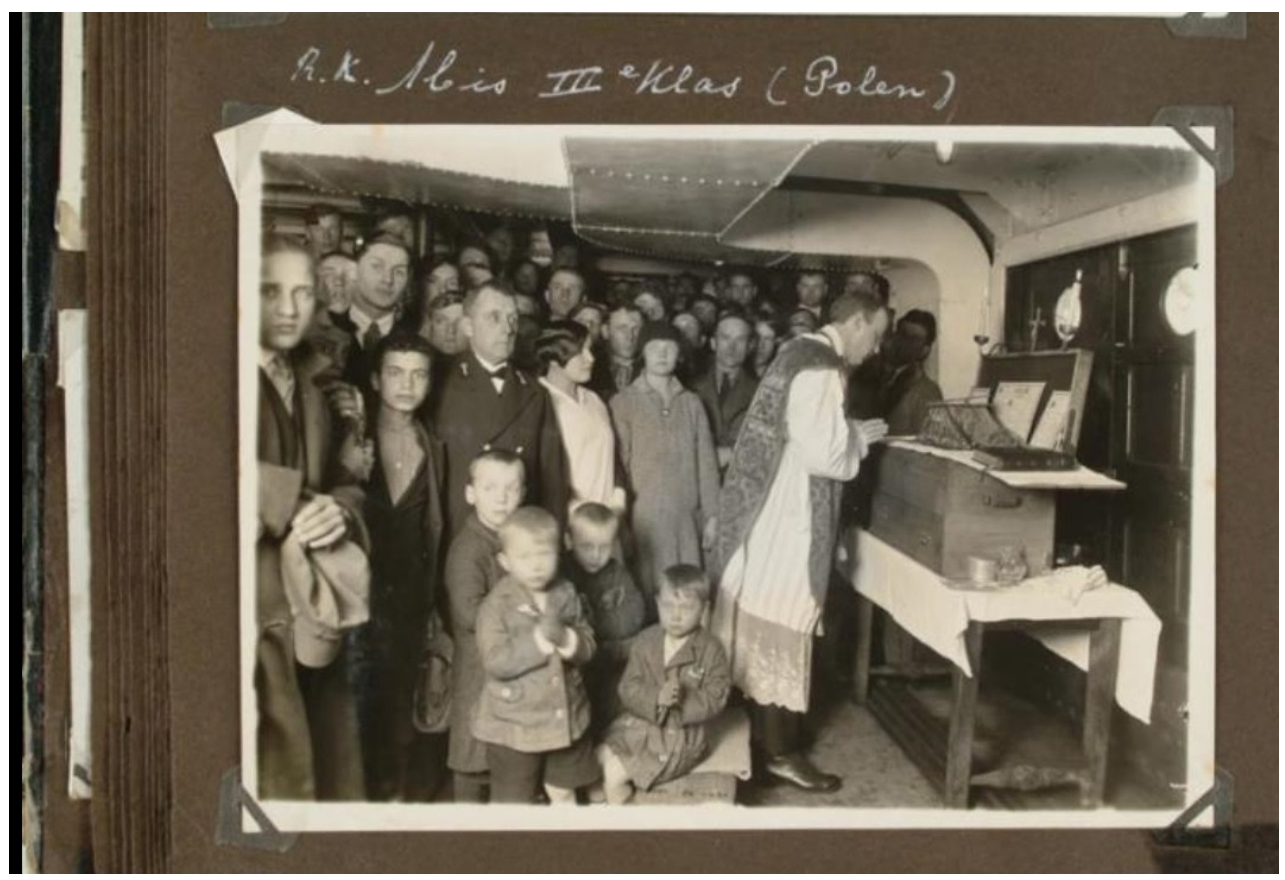

Figure 2. Photo by Jaap Zindler included in replica album based on Ite de Hoo's albums, Het Scheepvaartmuseum, the National Maritime Museum, Amsterdam.

\section{Expedition photos from the Arctic by William Grant}

Among the oldest images in the exhibition are William Grant's photographs from research expeditions in the period 1876-83. Grant (1851-1935) was from a wealthy English family and learned photography during his years in university. He had sufficient financial means to buy his own photo equipment and offer unpaid assistance to Arctic expeditions. He participated in both British and Dutch expeditions and brought home photographs from Greenland (Kalaallit Nunaat), the Barents Sea, Svalbard, and Novaya Zemlya. In this case, the replica album produced for the exhibition is based on several official albums, which were originally compiled with the aim of generating attention for the expeditions and securing funding for similar future excursions. Curator Daalder describes these albums as precursors of printed photo books, and since they are not personal albums, it was actually not his original intention to include 
them in the exhibition. However, Grant's photos were found to be particularly beautiful and their image content matched the chosen themes. ${ }^{8}$ In the introduction to the replica album, they are described as 'very important as the first photo reports of Dutch sea voyages.'

The inclusion of Grant's photographs was based on research performed at the museum by retired senior curator Willem J. F. Mörzer Bruyns (2003). The Dutch polar expeditions in the late nineteenth century were an attempt to regain earlier centuries' reputation of the Dutch as important Arctic explorers. The Dutch schooner Willem Barents, was named after the Dutch Arctic explorer of the same name (ca. 1550-1597), and the motivation behind the expeditions was partly nationalistic and imperialist: 'Dutch national pride was offended that recent travellers to the Arctic had renamed locations, ignoring the original Dutch place-names' (Mörzer Bruyns 2003: 124). Thus, in addition to collecting scientific data, the intention was to place commemorative stones 'at locations discovered by Willem Barents' (124). One of Grant's tasks was to photograph these monuments, and inclusion of such photos in The Photo Albums could be said to celebrate the achievements of the seafaring nation. However, the narratives framing the replica album foreground photo-historical aspects, as both the introductory text and the oral account stress how Grant's work shows his exceptional skills as a photographer, since the Arctic climate made his use of glass plate negatives and working conditions in the darkroom on board extremely difficult.

Mörzer Bruyns (2003) does not mention the collection of ethnographic data as an aim of the Arctic expeditions, but nevertheless Grant's photographs of indigenous people were included in the promotional albums. The Photo Albums includes photos of Inuit people in Greenland and Sámi in Norway. Recent Norwegian photo-historical research has identified similarities between photographs from polar expeditions and photographs made by missionaries and colonizers (Aarekol 2014; Høvik 2015). Lena Aarekol has described this joint photographic agenda as 'a broadly ethnographic focus on clothing, tools and material culture,' and stressed how photographs from polar exhibitions have 'contributed to shaping and delineating the view of indigenous people in polar areas' (2014: 155). Accordingly, Ingeborg Høvik (2015) argues that the Norwegian explorer, Roald Amundsen, was well aware of photography as a visual tool in anthropology. He adjusted his description of the Netsilik Inuit (Nunavut, Canada) encountered on the Gjøa Expedition (1903-06) to fit the anthropological views of the time, which described indigenous people as primitive and frozen in time. Høvik briefly mentions how such ethnographic conventions for visual representation of indigenous peoples also influenced publications about earlier nineteenth century Arctic expeditions (Høvik 2015: 154), and Grant's photographs may be ascribed to the same tradition of representation.

Representational ethics come into play with other photographs as well. In The Photo Album, two of Grant's ethnographic photographs are included in the themed hanging Local Population. One shows two Inuit men posing with a kayak and is presented with the original caption 'Eskimos with Kayak, Greenland 1878.' The other photograph is a group portrait of Inuit men, women, and children on the deck of the British expedition ship Pandora, and the caption reads 'Group of Eskimos on board the Pandora in Upernavik, Greenland 1876.' ${ }^{9}$ This group photograph is also used in the replica album, and furthermore, two photographs of Inuit summer camps on the coast of Greenland are included. A group photograph shows Inuit children and grownups in front of a tent and a Western European man standing a little to their right. Although this photo represents the coast as a contact zone, the original caption simply says 'Eskimos,' which is in line with the historical use of objectifying captions within anthropological archives although it is remarkable that the Western European man (possibly one of Grant's expedition colleagues) is not named but simply ignored (Edwards 2003). Another photograph is a scenic view of a bay with mountains and tents that look small in the impressive landscape. No people are visible, but the caption says 'Barden Bay with the summer tents of the wild Eskimos,' which reflects a view of Inuit culture as uncivilized. ${ }^{10}$ Apart from these original captions, the Inuit images are not framed by texts in the exhibition, and so visitors are invited to experience the photographs as a mediated encounter with 'primitive' indigenous people, while it might have been more appropriate if this 'misreading' had explicitly been pointed out as 'aberrant and invalid' (Edwards and Mead 2013: 32).

As mentioned earlier in the section on representational ethics, the use of old captions and derogatory terminology has been extensively discussed in relation to ethnographic museums 
(e.g., Edwards 2003; Edwards and Mead 2013). Eskimo can be considered an outdated term, which may be experienced as offensive by the people categorized as such. ${ }^{11}$ However, the term can still be encountered in museums, although primarily in online databases where the old term is often supplemented with the term Inuit. The Dutch ethnographic museum, Museum Volkenkunde, uses the term Inuit in their permanent exhibition, but according to the Dutch Wikipedia site, Eskimo is still the most commonly used term in colloquial Dutch (Wikipediabijdragers, 2016). ${ }^{12}$ Nevertheless, it remains problematic that the term is given without comment in the exhibition at the Scheepvaartmuseum, especially when used in a caption on 'wild Eskimos.' According to curator Daalder, the use of old captions was not discussed by the staff as the exhibition was created. This is another point, where more transparency could have strengthened the exhibition. ${ }^{13}$ Using the reflective strategies proposed by Edwards and Mead (2013) to question the term Eskimo could have disturbed the illusion of leafing through an old album and seeing the world through the eyes of the explorers, but by letting the captions stand without comment, this part of the exhibition inadvertently reproduces Arctic Orientalist discourses of bygone times (Jensen 2015).

Grant also photographed Sámi in Hammerfest on the island Kvaløya off the northwestern coast of Norway. One of these photographs is placed in the replica album (Figure 3). The original caption is 'Laplanders on the market in Hammerfest.' Four Sámi, presumably three men and a woman, are sitting on or leaning against barrels on the wharf. They may have been placed like this in order to be able to hold the pose during the long exposure time, as the curious on-lookers in the background are blurred.

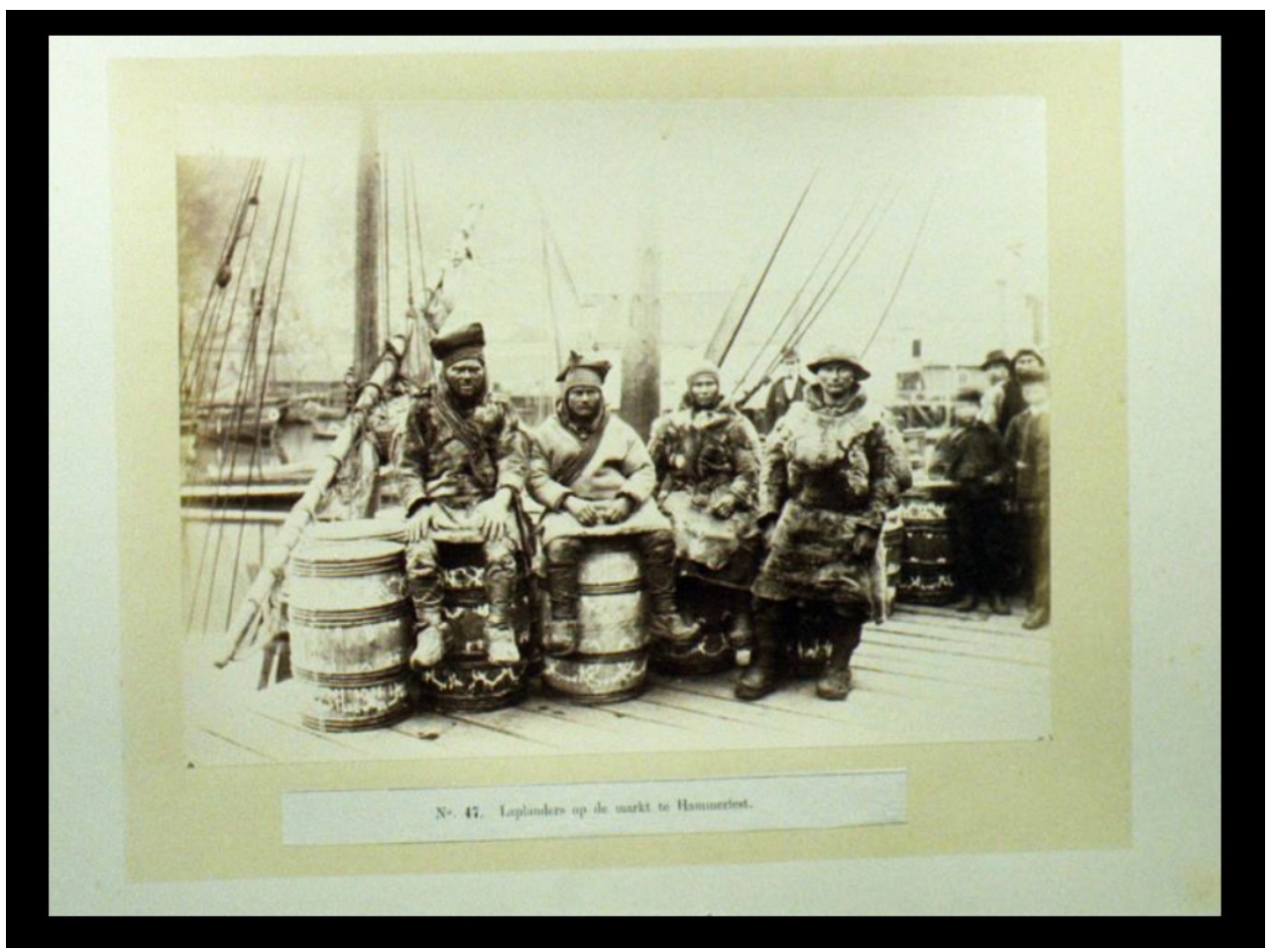

Figure 3. Photo from the replica album with William Grant's photographs. Het Scheepvaartmuseum, the National Maritime Museum, Amsterdam.

The oral story created for this replica album foregrounds this photograph as a fine example that illustrates Grant's skill in creating group portraits. The speaker further comments that the photograph gives 'a wonderful picture of the culture of the Northern nomads which is now 
virtually disappeared.' Visitors are not made aware that Laplanders are today known as Sámi, an acknowledged indigenous people, who have experienced a cultural revitalization since the Second World War. At the end of the nineteenth century, Norwegian politics toward the Sámi were aggressively assimilatory (Niemi 2008: 4). Ethnographic photographs of ethnic types as well as anthropometric photography were used to stress the distinctive physical traits of the Sámi, and such visual practices continued into the twentieth century (Dobbin 2013: 132). Research on the use of photographs in Sámi museums may instigate a sceptical and reflective approach to historical photographs, since the images often contain racializing strategies and are 'manifestations of the majority society's or outsiders' view of the Sámi' (Lien and Nielssen 2012: 297). Furthermore, Sámi artists have appropriated old photographs in critical art projects that contribute to the revitalization of Sámi memory culture (Dobbin 2013; Lien and Nielssen 2012; Lien 2014). In light of this Sámi suspiciousness of ethnographic photography, the representation in The Photo Album, which almost reproduces a nineteenth-century view of the Sámi culture as doomed to extinction, is unfortunate. Curator Daalder told me that the idea of adding oral accounts to accompany the replica albums came up late in the design process. ${ }^{14}$ The oral account could have been developed further in order to accommodate a more sensitive contextualization of the Sámi group portrait.

The Photo Albums opened in 2011 as part of the museum's new, permanent exhibition, and it is only fair to point out that much of the literature on the expedition genre and photographic representations of the Sámi, which I have drawn upon in my critique, have been published since that time. Grant's photographs are remarkable and absolutely worth showing in The Photo Albums, but nevertheless I will suggest a few adjustments, which could be made while retaining the overall design of the exhibition. Inclusion of the original captions in the exhibition is not necessarily or inherently problematic, and trying to avoid them would have disturbed the experience created by the use of the replica albums. However, the accompanying texts created by the museum could have framed Grant's photographs of indigenous groups better. Grant's ethnographic agenda could have been contextualized photo-historically within the expedition genre, which would have been in line with the main themes of the exhibition. This could, for instance, be done in the introductory texts to the replica albums, which could also include reflections on the original captions and introduce the more appropriate terms of Inuit and Sámi. Furthermore, the original captions could still be included in the thematic hanging Local Populations, as long as they were presented as 'original caption' and supplemented with more appropriate terms. These recommendations are important for other institutions as well, because they, too, must struggle with the dilemma of whether to use original, authentic captions or to include more contemporary perspectives on image content. Immersive technology, which supports removal of barriers that would remind viewers of the constructedness of museum experiences in favour of crating the 'realistic,' works in opposition to the impulse to contextualize and comment on exhibition objects, which invites visitors to take a more reflective approach. .

\section{Conclusion}

This article has examined The Photo Albums as an exhibition that foregrounds the photo collection of a maritime museum. The poetic room with creative use of fictitious materiality that totally avoids digital screens encourages an immersive visitor experience. My analysis has shown how the aesthetic design is to some degree at odds with the increased focus on materiality in recent photo-historical research. However, this could be remedied by more transparency about the choices made, without changing the overall creative and innovative design. The Photo Albums display exemplifies a permanent exhibition designed to last for numerous years, and adjustments could be made to update the representation in order to avoid outdated stereotypes and communicate respect for indigenous peoples. While anthropological museums have critically examined the use of colonial and ethnographic photographs from their collections, recent research has stressed an urgent need to address these issues in other types of museums (Edward and Mead 2013; Edwards and Lien 2014; Finch-Boyer 2014; Bessel 2015). Again, it is only fair to point out that these texts have been published after the creation of The Photo Albums, which testifies to the importance of an increased focus on new museum ethics and appropriate museology across different parts of the museum sector (Marstine 2011; 
Kreps 2015; Marselis 2016). As argued in this article, maritime museums need to take up the challenge of representational ethics in relation to their photographic collections, since their maritime heritage typically includes photographs that represent cultural encounters on foreign coasts. Otherwise, they risk perpetuating past power relations relating to contact between individuals from colonial powers and people in other parts of the world.

Received: 6 September 2017

Finally Accepted: 26 March 2018

Notes

1 Representational ethics in anthropological museums have been widely discussed within esearch inspired by postcolonial theory (see for instance Clifford 1997; Lidchi 1997; Harris and O'Hanlon 2013; Gladstone and Berlo 2011). For the purpose of this article, the author has focused on research on colonial photography in museums.

2 This wall text mistakenly gives the impression that film was commercially available, giving individual travelers and seamen the opportunity to make their own photographs long before that was actually the case. The older albums were thus compiled from photographs taken by professional photographers.

3 The Photo Albums was created in collaboration between staff at the museum and the German design bureau, Atelier Brückner. Senior Curator, Dr. Remmelt Daalder, has since retired, but was kind enough to let the author interview him about the exhibition (R. Daalder, telephone interview by author, digital recording, 19 January 2016, Copenhagen/ Amsterdam). The interview was thus made several years after the opening of the museum, and Daalder stated that he did not remember all discussions that took place during the design process. Nevertheless, the information gained during the interview was highly valuable for my analysis. In addition to thanking Dr. Daalder, the author would also like to thank Ernst van Keulen, senior educator and Sara Keijzer, curator of photography and film, both at Het Scheepvaartmuseum, for their help in providing information about and texts from the exhibition.

4 Remmelt Daalder, telephone interview, 19 January 2016.

5 Remmelt Daalder, telephone interview, 19 January 2016.

6 I have been able to examine the digitized version of the original albums on the Dutch, online platform Maritiem Digital, http://www.maritiemdigitaal.nl/. However, a photo-historical examination of the original albums and a close comparison with the replica albums are beyond the scope of this article.

7 Red Star Line Museum. 2016. “Highlights.”, http://www.redstarline.be/en/content/highlights Accessed October 5. 2016.

8 Remmelt Daalder, telephone interview, 19 January 2016.

9 By mistake, this photo is in the grouped hanging ascribed to Jan de Groot. However, the photo is one of Grant's and is also included in the replica album on his work

10 The captions in the replica album are in Dutch and scanned from the original album. The person behind these captions is not identified, but it is not likely to have been Grant as he was an Englishman. For the purpose of this article, the captions were translated into English by the author.

11 The use of the term Inuit instead of Eskimo is, for instance, promoted by the transnational organization Inuit Circumpolar Council. Inuit Circumpolar Council Canada (2010) 'The Use of the Term "Inuit" in Scientific and Other Circles.' http://www.inuitcircumpolar.com/-theuse-of-the-term-inuit.html, accessed 26 March 2018. 
12 Wikipedia-bijdragers, 'Eskimo's', Wikipedia, de vrije encyclopedie, https://nl.wikipedia.org/ wiki/Eskimo\%27s, accessed 23 March 2018.

13 Remmelt Daalder, telephone interview, 19 January 2016.

14 Remmelt Daalder, telephone interview, 19 January 2016.

\section{References}

Aarekol, L. (2014) 'Heroic Stories or Indigenous Perspectives? Polar Expedition Photographs in Norwegian Museum Exhibitions.' in Elizabeth Edwards and Sigrid Lien, (eds) Uncertain Images: Museums and the Work of Photographs, 149-62, Farnham: Ashgate.

Allen, M. (2013) 'The Conversation and Preservation of Photograph Albums in Archives.' in Graeme Farnell, (ed) The Photograph and the Collection: Create, Preserve, Analyze, Present, 156-68, Verticals: Writings on Photography. Edinburgh: MuseumsEtc.

Bessel, U. (2015) 'Unwrapping the Layers: Translating Photograph Albums into an Exhibition Context.' in Elizabeth Edwards and Christopher A. Morton (eds) Photographs, Museums, Collections: Between Art and Information, 215-29, London; New York: Bloomsbury Academic, an imprint of Bloomsbury Publishing Plc.

Clifford, J. (1997) 'Museums as Contact Zones.; in James Clifford (ed) Routes: Travel and Translation in the Late Twentieth Century, 188-219, Cambridge, Mass: Harvard University Press.

Crane, S. A. (2013) 'The Pictures in the Background: History, Memory and Photography in the Museum.' in Joan Tumblety (ed) Memory and History: Understanding Memory as Source and Subject, 123-39, London; New York: Routledge.

Dahlgren, A. (2010) 'Dated Photographs: The Personal Photo Album as Visual and Textual Medium.' Photography and Culture 3 (2) 175-94. doi:10.2752/17514511 OX12700318320431.

Dobbin, K. (2013) '“Exposing Yourself a Second Time": Visual Repatriation in Scandinavian Sápmi.' Visual Communication Quarterly 20 (3) 128-43. doi:10.1080/15551393.201 3.820585 .

Edwards, E. (2001) Raw histories: photographs, anthropology and museums, Oxford: Berg.

(2003) 'Talking Visual Histories: Introduction.' in Laura L. Peers and Alison K. Brown (eds) Museums and Source Communities: A Routledge Reader, 83-99, London; New York: Routledge.

Edwards, E., and Lien, S. (2014) 'Museum and the Work of Photographs.' in Elizabeth Edwards and Sigrid Lien (eds) Uncertain Images: Museums and the Work of Photographs, 3-17, Farnham, Surrey, England: Ashgate.

Edwards, E., and Mead, M. (2013) 'Absent Histories and Absent Images: Photographs, Museums and the Colonial Past.' Museum \& Society 11 (1) 19-38.

Edwards, E., and Morton, C. (2015) 'Between Art and Information: Towards a Collecting History of Photographs.' in Elizabeth Edwards and Christopher Morton (eds) Photographs, Museums, Collections: Between Art and Information, 3-23, London: Bloomsbury Academic. 
Finch-Boyer, H. (2014) 'Lascars through the Colonial Lens: Reconsidering Visual Sources of South Asian Sailors from the Twentieth Century.' Journal for Maritime Research 16 (2) 246-63. doi:10.1080/21533369.2014.971505.

Gladstone, M., and Berlo, J. C. (2011) 'The Body in The (White) Box: Corporeal Ethics and Museum Representation' in Janet Marstine (ed) The Routledge Companion to Museum Ethics: Redefining Ethics for the Twenty-First-Century Museum, 353-378, London, New York: Routledge.

Harris, C., and O'Hanlon, M. (2013) 'The future of the ethnographic museum.' Anthropology Today, 29 8-12. https://doi.org/10.1111/1467-8322.12003

Høvik, I. (2015) 'Framing the Arctic: Reconsidering Roald Amundsen's Gjøa Expedition Imagery.' Nordlit, 35 137-60. doi:10.7557/13.3431.

Jensen, L. (2015) 'Greenland, Arctic Orientalism and the Search for Definitions of a Contemporary Postcolonial Geography.' KULT, 12 140-53 http://postkolonial.dk/kult12-beyond-the-empires/

Kreps, C. (2015) 'Appropriate Museology and the "new Museum Ethics" Honoring Diversity.' Nordisk Museologi, 2 4-16.

Langford, M. (2001) Suspended Conversations: The Afterlife of Memory in Photographic Albums, Montreal; Ithaca: McGill-Queen's University Press.

(2006) 'Speaking the Album: An Application of the Oral-Photographic Framework.' in Annette Kuhn and Kirsten Emiko McAllister (eds) Locating Memory: Photographic Acts, 223-46, Remapping Cultural History, v. 4. New York: Berghahn Books.

Lidchi, H. (1997) 'The poetics and the politics of exhibiting other cultures' in Stuart Hall (ed) Representation: Cultural Representations and Signifying Practices, 151-222, London: Sage Publication.

Lien, S. (2014) 'The Aesthetic of the Bear Hunt: Contemporary Photography in the Ecology of a Sámi Museum' in Elizabeth Edwards and Sigrid Lien (eds) Uncertain Images: Museums and the Work of Photographs, 95-112, Farnham, Surrey, England: Ashgate.

Lien, S., and Nielssen, H. (2012) 'Absence and Presence: The Work of Photographs in the Sámi Museum, RiddoDuottarMuseat-Sámiid Vuorká-Dávvirat (RDM-SVD) in Karasjok, Norway' Photography and Culture 5 295-310. doi:10.2752/17514521 2X13415789392965.

Machin, D., and Mayr, A. (2012) How to Do Critical Discourse Analysis: A Multimodal Introduction, Los Angeles: SAGE.

Marselis, R. (2016) 'On Not Showing Scalps: Human Remains and Multisited Debate at the National Museum of Denmark' Museum Anthropology 39 (1) 20-34.

(2017) 'Photo Seeks Family: Digitization, Visual Repatriation and Performative Memory Work' in Amy Levin (ed) Global Mobilities: Refugees, Exiles, and Immigrants in Museums and Archives, 348-367. London: Routledge.

Marselis, R. and Schütze, L.M. (2013) 'One Way to Holland: Migrant Heritage and Social Media' in Kirsten Drotner and Kim Christian Schrøder (eds) Museum communication and Social Media: The Connected Museum, 75-92, London: Routledge. 
Marstine, J. (2011) The Routledge Companion to Museum Ethics: Redefining Ethics for the Twenty-First-Century Museum, London, New York: Routledge.

McCredie, A. (2015) 'From Them to Us: Changing Meanings of Photographs of Maori at Te Papa' in Elizabeth Edwards and Christopher A. Morton (eds) Photographs, Museums, Collections: Between Art and Information, 195-212, London; New York: Bloomsbury Academic, an imprint of Bloomsbury Publishing Plc.

Morton, C. (2014) 'Observations from the Interface: Photography, Ethnography, and Digital Projects at the Pitt Rivers Museum' in Elizabeth Edwards and Sigrid Lien (eds) Uncertain Images: Museums and the Work of Photographs, 243-60, Farnham, Surrey, England: Ashgate.

Mörzer Bruyns, W. F.J. (2003) 'Photography in the Arctic, 1876-84: The Work of W.J.A. Grant' Polar Record 39 (2) 123-30. doi:10.1017/S003224740200284X.

Nielssen, H. (2014) 'Photography and the Crisis of Ethnographic Display' in Elizabeth Edwards and Sigrid Lien (eds) Uncertain Images: Museums and the Work of Photographs, 55-72, Farnham, Surrey, England: Ashgate.

Niemi, E. (2008) 'Indigenous Peoples and National Minorities in Norway: Categorization and Minority Politics' in Katherine J. Goodnow, Haci Akman, and Unesco (eds) Scandinavian Museums and Cultural Diversity, Museums and Diversity, New York: Berghahn Books.

Pattynama, P. (2012) 'Tempo Doeloe Nostalgia and Brani Memory Community: The IWI Collection as a Postcolonial Archive', Photography and Culture 5 (3) 265-79.

Pattynama, P. (2014) 'Bitterzoet Indië: Herinnering En Nostalgie in Literatuur, Foto's En Films' [Bittersweet Indië: Memories and Nostalgia in Literature, Photos and Movies]. Amsterdam: Prometheus.

Pratt, M. L. (2007) Imperial Eyes: Travel Writing and Transculturation, 2. ed., Reprint. London: Routledge.

Sandweiss, M. A. (2002) Print the legend: photography and the American West (Nachdr.), New Haven, Conn.: Yale Univ. Press.

Sassoon, J. (2004a) 'Becoming Anthropological: A Cultural Biography of EL Mitchell's Photographs of Aboriginal People' Aboriginal History 28 59-86.

(2004b) 'Photographic Materiality in the Age of Digital Reproduction', in Elizabeth Edwards and Janice Hart (eds) Photographs Objects Histories: On the Materiality of Images, 186-202, London: Routledge.

Schokkenbroek, J.C.A. (2013) 'Setting Sails on a New Course! Het Scheepvaartmuseum in Amsterdam after Its Renovation', Drassana: Revista Del Museu Marítim 21 152-163.

Thomson, A. (2012) 'Family Photographs and Migrant Memories: Representing Women's Lives', in Alexander Freund and Alistair Thomson (eds) Oral History and Photography, 169-85, New York: Palgrave Macmillan.

Tinkler, P. (2012) "'When I Was a Girl . . .": Women Talking about Their Girlhood Photo Collections', in Alexander Freund and Alistair Thomson Freund (eds) Oral History and Photography, 45-60, New York: Palgrave Macmillan.

Wanhalla, A. (2007) 'In/Visible Sight: Māori-European Families in Urban New Zealand, 1890-1940', Visual Anthropology 21 (1) 39-57. 


\section{${ }^{\star R a n d i}$ Lorenz Marselis}

Associate Professor of Cultural Encounters

Department of Communication and Arts

Roskilde University

The aim of Rand's current research is to examine the role of websites and social media genres in the remediation of migration memories and heritage. She is particularly interested in, how social media genres may facilitate collaboration between museums and so-called 'source communities'. Furthermore, she is interested in, how colonial history and postcolonial memory practices are articulated in crossmedial communication (for instance across tv-documentarism, websites and social media).

Randi Lorenz Marselis

Associate Professor

Department of Communication and Arts

Interkulturelle studier

Kultur og Medier

Postal address:

Universitetsvej 1

43.3

DK-4000

Roskilde

Denmark

Email: marselis@ruc.dk

Phone: +45 46742174

Web: http://www.ruc.dk/ marselis 